УДК 141.7:165.4:165.212

DOI https://doi.org/10.32837/apfs.v0i32.1036

\author{
О. В. Солоділова \\ ORCID ID: https://orcid.org/0000-0003-3991-6721 \\ кандидат філософських наук, доцент, \\ доиент кафедри філософії, соиіології та історї \\ Дніпровського державного аграрно-економічного університету
}

\title{
ПРОБЛЕМА СПРИЙНЯТТЯ У ФІЛОСОФІЇ Т. АДОРНО
}

Постановка проблеми. Проблема сприйняття тенденційно стосується функціонування гуманітарних дисциплін у суспільстві, насамперед філософії, як поля розгортання онтології, когнітивістики, гносеології, аксіології, естетики й теорії культури (зокрема, іï паттернів, структур, образів і т. п.). Безпосередньо процес сприйняття має нейропсихофізіологічну природу як співвідношення людської психіки й когнітивних структур та зовнішнього середовища. На вищому, духовно-теоретичному рівні сприйняття тлумачиться як сприймання, як результат діяльності паттернів людської свідомості, взятих у їхній три структурній цілісності - ментальних, емоційних й тілесних, на найвищому рівні узагальнення - як усвідомлення й розуміння.

У цьому плані має значення англомовне тлумачення категорії «сприйняття» - «...Perception... 1. The act or faculty of apprehending by means of the sences or of the mind; cognition, understanding. 2. Immediate or intuitive recognition, as of moral or aestatic qualities...3. The result or product of perceiving, as distinguished from the act of perceiving; percept...» [22, с. 1069]. Наведене визначення дає нам чітке вказання на рівні процесу сприйняття-сприймання - від нейро-емоційно-психо-фізіологічного до ментально-мисленнєвого. Саме на цьому рівні має місце осмислення сутності зовнішньої інформації, яка надійшла до людини через її канали відчуття, соціокультурні комунікації.

Треба зазначити ще один важливий аспект розуміння цього процесу - його відношення до моралі, етики та естетики. У філософії процес сприймання має давнє походження; він набув інтенсивного розвитку в добу позитивізму та його розвитку, генези й розвитку герменевтики, феноменології, структуралізму та його сучасних філій, психоаналізу та його подальшого розвитку, ірраціональної філософії, екзистенціалізму, особливо в час постмодерну. Для нашого дослідження генеральне значення в цьому напрямі досліджень мають напрацювання Франкфуртської школи, особливо Теодора Людвіга Візенгрунда Адорно (Theodor Ludwig Wiesengrund Adorno; 1903-1969) - diлософа, соціолога, композитора, музикознавця. Свого часу Адорно набув великого авторитету в галузі філософії, соціології й музикознавства. У фазі активної творчої діяльності центром уваги Т. Адорно стали «рецесивні соціально-антропологічні зміни» (як стан відмирання рефлексії, заміна її стереотипними реакціями та уявними кліше тощо) $[17$, с. 38], їхнє соціально-філософське тлумачення було пов'язане з розвитком масової «індустрії культури", зі стандартизацією відносин у монополістичному суспільстві. Т. Адорно та його колеги цілісно усвідомили й узагальнили досвід фашистського режиму й радянського тоталітаризму, насамперед у сфері культури, розробили методологію розуміння впливу взаємодії суспільства й маскультури. Теодор Адорно дійшов висновку, що мистецтво є сферою, в якій втілюється «неідентичність» людини, що воно дає змогу вийти за межі позитивного сприйняття дійсності й доступності в сенсі розуміння досвіду Іншого [10].

У своїх роботах («Філософія нової музики», «Введення в соціологію музики», «Естетична теорія») Т. Адорно креатував теорію відокремлення об'єкта від суб'єкта в процесі сприйняття музичної творчості, ширше, культури, де продукт культурної, музичної творчості перетворюється на автономний суб'єкт. Адорно ранжував рівні сприйняття й розуміння музичної творчості (різних ï̈ лакун, перш за все, авангардної музики) й музичного виконавського мистецтва слухачем.

Концептуальна робота Т. Адорно «Естетична теорія» є спробою звернути увагу читача на трансцендентний досвід індивідуального та неідентичного у сприйнятті мистецтва. На думку Т. Адорно, витвір мистецтва уподібнюється до непізнаваної природи; це пов'язано з тим, що він, будучи багатоманітною соціокультурною формою, має ідентичне відношення до природи як автономного суб'єкта, у вигляді передчуття або рефлексу.

Т. Адорно розуміс мистецтво як стан його природної об'єктивності, що спровокованим чином впливає на людину, яка сприймає цю естетику. Водночас Адорно вважає продукт мистецтва «недосконалим», незавершеним, таким, що «вислизає» від людського розуміння [20].

у сучасному суспільстві проблеми, порушені Теодором Адорно, мають актуальне значення. Нині сприйняття культури взагалі і музичного мистецтва зокрема ускладнюється багатьма 
чинниками, які стали трендами в добу глобального інформаційного суспільства - в час багатоманіття жанрів, стилів, напрямів, тощо культури. Пересічна особистість у сучасному суспільстві стала заручником маніпулятивної, сфальшованої соціокультурної інформації, особливо її віртуального змісту й відповідних форм. Тотальний вплив масифікованих форм культури, зокрема мистецтва, призвів до соціокультурної деідентифікації індивіда, спричинив фрагментацію свідомості сучасної людини, яка опинилася сам на сам із хаосом поглядів, орієнтацій, ціннісних настанов та ін. Суспільство масової культури й споживання глобально впливає як на індивідуальні смаки й погляди, так і на загальний стан культури.

Сучасна філософія освіти, педагогіка, виховання активно застосовують напрацювання з теорії й практики Теодора Адорно, який став піонером у галузі соціології музики, філософії сприйняття музики. Його філософські, музикознавчі погляди не втратили актуальності й потребують творчого застосування в системі освіти й виховання, зокрема мистецької освіти, яка набула новітнього сенсу й змісту в сучасному інформаційному суспільстві, в соціокультурі постмодерну. Вимагають подальшого розвитку як загальна філософія, так й її лакуни - соціальна філософія, гносеологія, аксіологія, естетика, в тому числі антропологія, що не може обійти увагою комплексний процес сприйняття, в нашому випадку - мистецтва, його яскравої й вічно живої філії - музики - як спрямованості на співдію музичної творчості та людей, які її сприймають.

Аналіз останніх досліджень i публікацій. Нині в Україні є певна кількість наукових матеріалів, які характеризують й актуалізують творчість Т. Адорно. Матеріали від В.М. Брижнік [4], Л.Є. Юріної [19] вводять нас у світ об'єкт-суб'єктних відносин, що були екстрапольовані Адорно на світ музики: «...Якщо індивідуальність критично ставиться до твору, то й твір критично ставиться до індивідуальності. Якщо випадковий характер індивідуальності протестує проти ницого суспільного закону, <..> то твір містить начерки схем подолання такої випадковості...» [1]. В. Кебуладзе [8] апелює до Горкхаймера й Адорно в сенсі зв'язку абсолютно вільної краси з абсолютно автономним розумом [21, с. 15$]$ : сутність їхньої позиції полягає в тому, що в абсолютній чистоті чистого розуму розчиняються чуттєві відмінності; ідеальність ідеї не залишає місця для «недосконалості» реального розмаїття чуттєвого досвіду.

Філософсько-освітні колізії насамперед у сенсі сприйняття особистістю культури, притаманні сучасному баченню ідей Теодора Адорно, розкриті в працях М.Д. Култаєвої [11], I.I. Федорової [18], П.Б. Косенка [9].

У галузі аналізу соціології музики,"започаткованої Т. Адорно, є цікавою позиція Л.М. Гаврильчик.
Автор наводить цитату Адорно, який припускає, що музичні твори «...самі по собі є осмислені $<. . .>€$ об'єктивні структури, які <...> можуть бути сприйняті та пережиті в досвіді...» [7, с. 112]. Також, на думку Л.М. Гаврильчик, Адорно робить наголос на якісному характері сприйняття музики, яка не піддається позитивному вимірюванню через свою суб'єктивність [7, с. 112].

Т. Адорно вважав наріжним каменем типології слухачів музики не свідомість суб'єкта сприйняття, а об’єкт сприйняття. Сюжет заміщення правдивого відчуття естетичної насолоди від сприйняття мистецтва поверховим, заземленим почуттям задоволення, був вірно підмічений А.О. Васюріною, яка навела слова Адорно: «...той, хто насолоджується творами мистецтва як такими, <...> є обиватель і неук; його видають такі слова, як “райська музика"... " [5, с. 180]; відповідно до Адорно, інколи насолоду плутають із почуттям задоволення, яке може сягнути стану сп'яніння через властивість мистецтва надати людині ілюзію звільнення від «нікчемного»; Адорно припускає, що чуття насолоди від мистецтва пов'язане з відчуттям щастя від його пізнання, як «...пізнання справедливого, об’єктивного <...>, щоб і його істина, <...> його неістина були зрозумілими...» [5, с. 180]. O.М. Полтавцева [15] звертається до музичної естетики Адорно, яка є водночас критичною - як щодо «граничного витоньшування музикою своєї тілесності», так і щодо її перетворення на «соматичний ерзац» (у випадку «легкої музики»), або на дещо механічне, позбавлене суб'єктивності ( «дшіi), як озвучування «шизофренічних» станів тіла [17, с. 13].

О.П. Наконечна [13] акцентує на змісті естетичної раціональності від Т. Адорно, який підкреслив суперечливість чуттєвості і понятійності - філософом вони були розглянуті не як логічні структури наукового пізнання, а як фундаментальні виміри людського способу буття. Т. Адорно вважав незавершеність, відкритість смислів, навіть загадковість (у сприйнятті творів мистецтва) іманентно властивими естетичній раціональності, що спрямована на свободу мислення, утвердження самоцінності життя в його онтологічній безпосередності. На думку В.П. Культенко [12], акцент Адорно на неповторності та одиничності феномена суб'єкта (справжнього витвору мистецтва - O.С.) має значення оцінки його елітарного сприйняття в умовах масової культури.

Л. Боровська звертається до висновків М. Горкхаймера та Т. Адорно стосовно проблеми маніпуляції суспільною свідомістю, яка є основним трендом у комплексі сприйняття культури масового типу, що стандартизує процес естетичного сприйняття людьми її витворів; на їхню думку, люди втрачають потребу осмислити сутність «шаблонної» культурної продукції, людей «привчають» до 
неї, не пропонуючи альтернативи, примушуючи споживати «те, що дають» [3, с. 69].

Орієнтуючись на ідею страждальності як універсальний принцип (художнього) сприйняття, який фіксує предметну реальність, засновану на подвоєнні позитивного у формі самозаперечення, естетика негативності (Т. Адорно) є феноменом «шокового афекту» [2, с. 37], зближуючись із когнітивними студіями, що фокусують увагу на тілесно-соматичному стані людини, «...утворюючи граничну безпосередність суспільного буття...» [2, с. 25] - через активізацію тілесно-соматичного досвіду суб'єктивності [2, с. 36], який своєю чергою спрямовується в духовне самопочуття людини. Т.М. Рябуха [16] підкреслює значущість висновків Т. Адорно стосовно залучення людей як до активного сприйняття «високої» культури, так і до їхньої участі у творчості, до впровадження високих морально-етичних ідеалів. А.П. Начев [14] звертається до творчості Адорно в контексті впливу морально-естетичних цінностей на процес сприйняття особистістю суспільства та його естетичної складової частини.

Погляди зазначених авторів будуть застосовані як основоположний матеріал стосовно викладу основних тез, ідей та положень, які характеризують філософські погляди Теодора Адорно насамперед у світлі сучасних підходів до проблеми сприйняття у філософському контексті.

Мета статті - розгорнути об'єкт-суб'єктний аналіз проблеми сприйняття, яка є однією із ключових у філософсько-соціологічній системі Теодора Адорно, застосувати певні положення з його праць у напрямі напрацювання методології сприйняття культури, музичної творчості в умовах глобального інформаційно-духовного суспільства.

Виклад основного матеріалу. У концептуальній роботі «Естетична теорія» Теодор Адорно у підрозділі «Естетичне сприйняття, яке розглядається аналітично» [1] співвідніс індивідуальне й надіндивідуальне в сенсі раціонального осмислення суспільством і людиною феноменів культури, музичної зокрема. Цю раціональність Адорно протиставив позасвідомому, що було культивовано в добу Просвітництва. 3 метою запобігання тотальності раціонального Адорно протиставляє йому спонтанне, яке, на думку дослідника, є основним культурно-музичним трендом доби. Воно $\epsilon$ формою адекватного пізнання естетичного стосовно перебігу об'єктивних процесів, що вони (через твір мистецтва) виражають складну напруженість протиріч, які йому притаманні [1, с. 103].

Також ми повинні розуміти, що, будучи вихованцем європейської класики (філософської й музичної), Теодор Адорно стикнувся в США із засиллям масової культури. Філософ зробив висновок: «капіталістична» масова культура обмежує свободу громадянина, маніпулюючи його свідомістю, звужуючи рамки його сприйняття культури. Потенційно Адорно міг би протиставити цій культурі свій снобізм й прихильність до елітарного мистецтва, музичного зокрема (в якому він перебував у статусі топового критика).

Фактично Адорно наголосив на двополюсності сучасної йому культури та перевагах й недоліках полюсів. Якщо масова культура, з погляду Адорно, знижує якісний рівень сприйняття пересічного громадянина через шаблони, стереотипи й стандарти, то елітарна, навпаки, підвищує рівень духовного сприйняття витворів мистецтва, але разом із тим звужує коло таких громадян, залишаючи їх без вибору інших можливостей, які надає культура. У своїй «Теорії естетики» Т. Адорно відштовхувався від традиційних підходів до сутності смаку й розглядав цей феномен у рамках власної концепції критичної свідомості [6, с. 42].

Критерієм таких спрямувань свідомості особистості, у сенсі сприйняття витворів мистецтва, музичного зокрема, Т. Адорно вважав насолоду, почуття щастя - у глибоких його морально-етичних, естетичних вимірах. Але в умовах капіталістичного способу життя, який висуває на фронтальне місце зманіпульовану, фальшиву, поверхневу насолоду (вона має на меті, перш за все задовольнити «найпростіші» потреби людини - O.С.), філософ вважав, що ця насолода фальшує слідування істинній природі і спрямованість призначення людини - бути гармонійно розвиненою. Більше того, цій насолоді філософ надавав метафізичного надіндивідуального статусу, методологічно обертаючи витвори високого мистецтва на автономні об'єкти буття.

На думку Т. Адорно, поп-культура позиціонує себе як вивільнення людей, при цьому вона позбавляє людей свободи двічі - в естетичному сенсі (вона не є здатною надати дати естетичну свободу людині стосовно сприйняття й розуміння високого мистецтва та етично (вона блокує свідомісний шлях людини до істинної соціальної свободи). Теодор Адорно мав на увазі свободу, яка стосується переживання, інтерпретування та розуміння творів мистецтва; така свобода вимагає від твору мистецтва давати людині простір і час, щоб особистість могла ним повноцінно емоційно й духовно перейнятися, відчути його як неподільне надіндивідуальне ціле. Адорно піддав критиці масову культуру, яка, на його думку, втратила свою здатність створювати "високі» твори; іï продукцію Адорно відобразив такою, що переслідує інстинктивні людські начала, слугуючи суто «низьким» задоволенням.

Великим здобутком у цьому сенсі (Т. Адорно й М. Горкхаймера) є винайдення ними суспільного феномена масового суспільства й масового споживання - «індустрія культури». Саме вона, на думку Адорно, привчає пересічного споживача 
культурної продукції зосереджуватись на хвилинних інтервалах часу та змісту, акцентованих спровокованих фрагментах творів різних жанрів, затупляючи таким чином людську здатність й готовність сприймати твори мистецтва як єдиних, комплексних об'єктів, які, за висновками Адорно, мають надіндивідуальний характер, містять у собі фундаментальні естетичні властивості - емоційні, ментальні, які разом із тим є незалежними від свідомості людини.

У роботі «Діалектика освіти» (1947) Адорно й Горкхаймер уподібнили масову культуру до виховання, яке зваблює людину до своєї «відчуженої» царини, закріплюючи у свідомості людини шаблони мислення та саморозуміння, що в кінцевому рахунку завдає великої шкоди людській здатності жити справжнім вільним життям. Іншим негативним наслідком тотального впливу масової культури (за Адорно - О.С.) є їі настирливість, наступальність - вона охоплює весь вільний простір й час людини, яка живе в «капіталістичному, монополістичному» суспільстві. Того більше, масова культура породжує новітній необмежений простір, що в ньому місце справжньої, морально й когнітивно високої культури, тотально звужується. Тепер «висока» культура є виключно справою обмеженого кола поціновувачів, яким доводиться долати певні бар'єри на шляху залучення до неї.

Радикалізм Адорно проявився в тому, що мислитель заперечив ціполюси культури, - у 1960-і pp. філософ був підданий «анафемі» як «високочолими» інтелігентами, так і бунтарями (які впроваджували різноманітні форми контркультури, андеграундної культури - O.С.). Також зважати на факт перебування Теодора Адорно в середовищі Франкфуртської школи, що вона позиціонується як неомарксистська. У цьому контексті треба зауважити, що на культурний рух у США, як і у Західній Свропі в цей час мали потужний вплив ліві настрої та активне поширення авангардної культури - предтечі постмодерну.

Для нашого дослідження має методологічне значення позиції Теодора Адорно, який диференціює єдність особистісної свідомості на індивідуальне та надіндивідуальне, на внутрішній та зовнішній виміри, що надає автору теорії можливість проявити позицію трансцендентальної філософії в умовах масового суспільства [4, с. 101]; таким чином Адорно стверджує «діалектичне сприйняття загального і особливого...» [20, с. 144]. 3 позиції «негативної діалектики» це означає, що особиста присутність людини в соціальному бутті, суб'єкт якого отримує статус трансцендентального діяча (витвір мистецтва - O.С.), теоретично усувається зі сфери суспільних оцінок. У такому спрямуванні цей зразок трансцендентального мислення постає висхідним моментом інтелектуальної підтримки впливу на носія індивідуальної свідомо- сті, надаючи водночас цьому суб'єктові автономність, відсторонюючи його зі сфери раціонального осмислення суспільно необхідних смислів. Таким чином, у просторі системної раціональності, організованої цим типом мислення, суб'єкт постає інтелектуально нейтралізованим (маються на увазі реальності масової культури - О.С.); він «відступає» стосовно образу «множини світового процесу», відмовляючись від його конструювання способами, «природно властивими розуму». У такий спосіб, на переконання Адорно, системна інтеграція суб'єкта здійснюється як соціальна дезінтеграція. Її об'єктивним наслідком стає ірраціональність реальності. У результаті свідомість людини фрагментується, перестає бути ідентичною й цілісною; світ сприйняття людини набуває «мозаїчно» нетривкого, збідненого - емоційно й когнітивно, - характеру, «Я» людини тенденційно перетворюється на предмет надв'язуваної раціоналізації, пасивно відмовляючись від природної конститутивної функції. 3 погляду онтології й антропології це означає, що самість стає річчю, об’єктом владного маніпулювання. Стається морально-естетичне відчуження свідомості суб'єкта, який діє й пізнає.

На переконання Адорно, онтологічні поняття, опосередковуючи суще, раціоналізуються наявним соціальним буттям, яке своєю чергою активізується через відокремлення від природного світу (як безпосередньо даного в свідомості - О.С.). У результаті цей процес суперечить філософському мисленню, основоположною рисою якого є незамкнення в безпосередньому сприйнятті фактичного.

Адорно впевнений, що суб'єкт (сприйняття - O.C) є інтелектуально нездатним до критичного сприйняття поза змінами у своїй свідомості. Філософ вказує на неможливість одночасної реалізації діалектичних перетворень в індивідуальній свідомості та реалізації змін у колективній свідомості, оскільки вони є структурно відмінними; він вважає за необхідне активізацію соціального буття через критичне мислення, яке водночас руйнує усталену раціональність, що когнітивно формує життєву реальність. На думку Адорно, таке перетворення здатний здійснити виключно носій індивідуального духу, суб’єкт, який перманентно знаходиться в процесі автономного мислення [20, с. 139].

У результаті активної перетворювальної діяльності свідоме відокремлення суб'єкта критичного мислення від свого об'єкта - соціального буття (за Адорно - О.С.) - набуває статусу соціальної дії. Таким чином, суб'єкт отримує ключ до когнітивної емансипації, до здатності самостійно сприймати соціальне буття, певним чином налаштовуючись осмислено заперечувати соціокультурний застій як наслідок ідеологічного тиску, здобуваючи таким чином наснагу автономно формувати ідентичне сприйняття світу. 
Висновки. Теодор Адорно, реагуючи на виклики з боку тоталітарного суспільства й суспільства масового споживання й культури, розробив власну теорію стосовно сприйняття суб'єктом соціокультурної дії явищ, як загалом суспільних, так і суто естетичних. Філософ методологічно розвів індивідуальне й надіндивідуальне сприйняття явищ культури, насамперед музичної, наділивши культурний продукт суб'єктивними якостями. Адорно розробив теорію «поляризації» культур у суспільстві масового споживання, масової культури. У результаті він заперечив обидві, проголосивши основним методологічним трендом свободу - соціальну, естетичну, стосовно пересічного громадянина, який опинився на перехресті цих культур. На думку Адорно, досягти адекватності в цій площині може особистість, яка критично мислить, формує власний світ культури, активно опирається пролонгованим намаганням суспільства, бізнесу, реклами, ЗМI та ін. перетворити людину на прислужника примітивних, неодухотворенних задоволень й насолод.

Вважаємо, що проблеми, задані й певним чином розкриті Теодором Адорно, не втратили актуальності. Сучасна філософія, яка спирається на об'єктивні й правдиві дані соціології, психології, освіти, культурного розвитку, має забезпечити розробку новітньої методології людини культурної, що ідентично поєднує у своїй свідомості загальнолюдські, регіональні й локальні цінності, виховує в собі здатність до критичного мислення, активно комунікує з приводу сучасних соціокультурних тенденцій, що потужно проявляють себе в добу постмодернізму, тотального віртуалізму, засилля інформаційних методів і технологій, сучасних проявів візуальної культури.

\section{Jimepamypa}

1. Адорно Т. Теорія естетики. Київ, 2002. 518 с.

2. Бондарчук I.А. Негативна діалектика як естетика : автореф. дис. ...д-ра філос. наук : 09.00.04. Київ, $1992.46 \mathrm{c}$.

3. Боровська Л. До витоків проблеми інституалізації засад десуб'єктивації людини. Вісник Київського національного торговельно-економічного університе$m y$. 2016. № 2. C. $66-74$.

4. Брижнік В.М. Онтологія Теодора Адорно - теорія нетотожності суб'єкта та об'єкта соціального пізнання. Політологічний вісник. 2013. Вип. 70. С. 97-109.

5. Васюріна А.О. Гедоністичність сприйняття просторової досконалості музичного світу. Сучасна карти на світу: інтеграція наукового та позанаукового знання : збірник наук. праць. 2004. Вип. 3. С. 175-181.

6. Воєводін О.П., Горохова О.В. Естетична оцінка : монографія. Луганськ, 2010. 140 с.

7. Гаврильчик Л.М. Типологія слухача музики в соціології музики Теодоро Адорно. Науковий часопис НПУ імені М. П. Драгоманова. Серія 14. Теорія і методика мистещької освіти. 2011. Вип. 12. С. 112-116.

8. Кебуладзе В. Користь краси й автономія розуму. Філософська думка. 2015. № 2. С. 15-20.

9. Косенко П.Б. Музичне навчання як детермінанта творчого розвитку особистості. Науковий журнал НПУ імені Драгоманова. 2019. Вип. 26. С. 35-42.
10. Кузнецов М.М. Адорно Теодор. Электронная библиотека Института философии РАН.

11. Култаєва М. Освіта та іï̈ деформації у сучасній культурі: до актуальності теорії напівосвіти Т. Адорно у сучасних соціокультурних контекстах. Філософія освіти. 2017. № 1. С. 153-195.

12. Культенко В.П. Феномен глобалізму та антиглобалізму в контексті філософського осмислення мистецтва авангардизму та сюрреалізму. Вісник Харківсько20 національного університету імені В. Н. Каразіна. Серія : Теорія культури і рілософія науки. 2012. № 995. Вип. 46. С. 53-57.

13.Наконечна 0.П. Естетичне як тип духовності : автореф. дис... д-ра філософ. наук : 09.00.08. Київ, 2004. 34 с.

14.Начев А.П. Ціннісні орієнтації особистості в контексті інформатизації суспільства : автореф. дис. ... канд. філос. наук : 09.00.03. Одеса, 2014. 19 с.

15. Полтавцева О.М. Антропологія музичної тілесності : автореф. дис... канд. філософ. наук : 09.00.04. Харків, 2005. 19 с.

16. Рябуха T.М. Витоки та інтонаційні складові української пісенної естради : автореф. дис. ...кандидата мистецтвознавства : 17.00.03. Харків, 2017. 20 с.

17. Сюсель Ю. Соціофілософський аспект споживацької поведінки як комунікативної дії : монографія. Київ, 2017. 182 с.

18. Федорова I.I. Творчий потенціал освіти в умовах аксіологічного релятивізму сучасного суспільства. Вісник Національного технічного університету України «Київський політехнічний інститут». Філософія. Психологія. Педагогіка. 2011. № 2. С. 169-173.

19. Юріна Л.Є. Українсько-німецькі перехрестя: естетика Маурісіо Кагеля як імпульс для творчих експериментів Сергія Зажитька. Київське музикознавство. № 59. Світова та вітчизняна музична культура: стилі, школи, персоналії. 2019. С. 100-111.

20. Adorno Theodor W. Negative Dialektik. Fr. am M.: Suhrkamp, 1990. 402 p.

21. Horkheimer M. Dialektik der Aufklarung. Philosphische Fragmente. Th. W. Adorno. Frankfurt a. m., $1969.258 \mathrm{p}$.

22. The Random House Dictionare of the English Language. Jess Stein, editor in Chief. Laurence Urda. 1975. $2059 \mathrm{p}$.

\section{Анотація}

Солоділова О. В. Проблема сприйняття у філософії Т. Адорно. - Стаття.

У статті розглянуто особливості проблеми сприйняття у філософії Т. Адорно. Його творчість відбувалася на тлі великих суспільних й культурних перетворень в XX столітті. Будучи філософом, культурологом, соціологом, музикознавцем, Т. Адорно напрацював свою теорію «негативної діалектики», в межах якої диференціював індивідуальне й надіндивідуальне, особливе й загальне. У статті обгрунтовано, що основним здобутком Т. Адорно $€$ його тлумачення витвору мистецтва, музичного, зокрема, як самостійного автономного суб'єкта, що має трансцендентний характер. Таким чином, раціональному позитивному мисленню - як суспільному, так i індивідуальному, що набуло своїх характерних рис у час розвитку авангардного мистецтва, народження Постмодерну, добу панування суспільства масового споживання й масової культури (поп-культури), яке певним чином стандартизує мислення, віддаючи перевагу масовим 
формам мистецтва й масовій музичній культурі, Адорно протиставляє процес безпосереднього сприйняття слухачем й глядачем культури, музики на рівні об'єктивного існування витвору мистецтва, який водночас має автономну суб'єктивну природу. Окреслено, що основним мотивом цієї «безпосередності» стала (в теорії Адорно) спонтанність - як безпосередній вияв людиною своїх почуттів, як вияв раціональної й ідеологічної незаангажованості. Адорно мав на увазі паритет індивідуального й надіндивідуального, що мав би дати людині ширший простір у сенсі виявів свободи - соціальної, естетичної й т. п. Також це давало змогу Адорно своєрідно підійти до актуального вирішення основної проблеми тогочасної (й, на нашу думку, нинішньої ) культури - співвідношення двох полюсів культури - «високої» елітарної й «низької» масової. Адорно заперечив обидві, висунувши тезу щодо необхідності вивільнення людської свідомості з кола будь-яких обмежень - соціальних, естетичних й т. ін. Доведено, що кінцевою метою такого вивільнення Адорно вважав досягнення певного рівня соціокультурної активності індивіда, який є здатним творчо переробити не тільки себе, але й суспільство, яке, з одного боку, стало супер раціональним, а з іншого - супервпливовим щодо свідомості людей, які стали заручниками тоталітарного способу мислення й життя, учасниками становлення нового «монополістичного» суспільства.

Такі погляди Адорно цілковито відповідали настановам й орієнтаціям Франкфуртської школи. Разом із тим Адорно став стійким об'єктом критики - як із боку авангардних інтелектуалів, так і з боку лівацьки налаштованих кіл, які стали основним конфронтаційним фоном тодішнього західного істеблішменту. Нині людство перейшло до життя в інформаційному глобальному візуалізованому цифровому суспільстві, де значно підваженими виглядають морально-ціннісні норми минулого, інтенсивно переглядаються естетичні настанови, орієнтації, смаки, зрештою, активно формуються новітня філософія, антропологія, філософія освіти й педагогіка, які мають дати відповідь на світоглядні й морально-етичні виклики сучасного суспільства.

Ключові слова: Т. Адорно, сприйняття, суб'єкт, об’єкт, культура, свідомість, твір мистецтва.

\section{Summary}

Solodilova $O$. V. The problem of perception in the philosophy of T. Adorno. - Article.

The article considers the peculiarities of the problem of perception in the philosophy of T. Adorno. The work of Theodore Adorno took place against the background of the great social and cultural transformations that took place in the twentieth century. As a philosopher, culturologist, sociologist, musicologist, Theodore Adorno developed his theory of "negative dialectics", within which he differentiated between individual and supra-individual, special and general. The article substantiates that Theodore Adorno's main achievement is his interpretation of a work of art, music, in particular, as an independent autonomous subject that has a transcendent character. Thus, rational positive thinking - both social and individual, which acquired its characteristics during the development of avant-garde art, the birth of Postmodernism, in the era of society of mass consumption and mass culture (pop culture), which in some way standardizes thinking, giving Adorno opposes the process of direct perception by the listener and viewer of culture, music at the level of the objective existence of a work of art, which, at the same time, has an autonomous subjective nature. It is outlined that the main motive for this "immediacy" was (in Adorno's theory) spontaneity - as a direct manifestation of human feelings, as a manifestation of rational and ideological disengagement. Adorno meant the parity of the individual and the superindividual, which should give man a wider space in the sense of manifestations of freedom - social, aesthetic, etc. today's) culture - the ratio of the two poles of culture - "high" elite and "low" mass. Adorno denied both, arguing the need to free human consciousness from any restrictions - social, aesthetic, etc. It is proved that the ultimate goal of such liberation Adorno considered the achievement of a certain level of sociocultural activity of an individual who is able to creatively transform not only himself but also society, which, on the one hand, has become super rational and, on the other, super influential. Became hostages of a totalitarian way of thinking and living, participants in the formation of a new "monopolistic" society. Adorno's views were fully in line with the guidelines and orientations of the Frankfurt School. At the same time, Adorno became a constant object of criticism, both from avant-garde intellectuals and leftwing circles, which became the main confrontational background of the then Western establishment. Today, humanity has moved to a state of life in the information global visualized digital society, in which the moral and value norms of the past look significantly undermined, aesthetic guidelines, orientations, tastes are intensively revised pedagogy, which should respond to the worldview and moral and ethical challenges of modern society.

Key words: T. Adorno, perception, subject, object, culture, consciousness, work of art. 